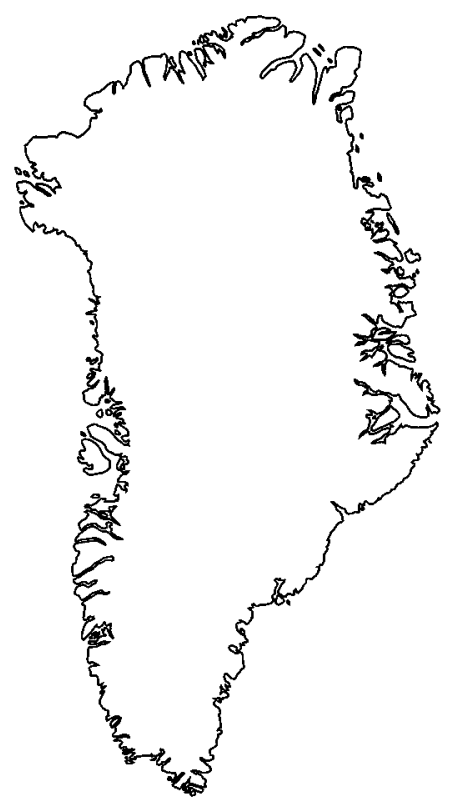

\title{
Upper Permian foraminifera from East Greenland
}

\author{
Jack Pattison \& Lars Stemmerik
}

\begin{abstract}
Foraminiferal assemblages recorded from limestones of the Upper Permian Wegener Halvø Formation in the Wegener Halv $\varnothing$, Karstryggen and Clavering $\varnothing$ areas of East Greenland mostly consist of the nodosariid genera Dentalina, Frondina, Geinitzina and Ichtyolaria, and the miliolid genera Agathammina and Calcitornella. More limited assemblages dominated by Agathammina were recorded from the underlying Karstryggen Formation. The foraminifera are all benthonic, mostly shallow-water forms. The fauna is of Zechstein aspect and suggests a broad correlation with Zechstein 1 and younger strata in the Zechstein basin of North-West Europe.

Solid specimens of agglutinated foraminifera, mostly referable to Ammobaculites and Ammodiscus, were recorded from the youngest Permian strata, the Schuchert Dal Formation, in the Schuchert Dal.
\end{abstract}

J. P., 372 Loughborough Road, West Bridgford, Nottingham, NG2 7FD, U.K. (formerly of the British Geological Survey).

L. S., Geological Survey of Denmark and Greenland, Thoravej 8, DK-2400 Copenhagen NV, Denmark.

The Upper Permian basin in East Greenland has been studied intensively over the last ten years in association with onshore hydrocarbon activity in the region, and the overall depositional history is well described (Surlyk et al., 1986; Scholle et al., 1991; 1993; Stemmerik, 1987; 1991; Stemmerik et al., 1988; 1993; Stemmerik \& Piasecki, 1991; Christiansen et al., 1993). However, studies of the Upper Permian fauna have been very limited since the pioneer work by Dunbar (1955) on the brachiopods and Newell (1955) on the bivalves. Recent stratigraphic studies include work by Piasecki (1984) and Utting \& Piasecki (1995) on the palynostratigraphy and by Rasmussen et al. (1990) on the conodont fauna.

The East Greenland Basin is situated midway between, to the south, the evaporitic Zechstein basin and adjacent Bakevellia Sea basin in north-west Europe, and, to the north, the cold temperate basins of North Greenland, Spitsbergen and the Barents Sea. It thus provides important information on the Late Permian faunal provinces in the North Atlantic region. This paper describes, for the first time, the Upper Permian foraminiferal fauna from East Greenland and discusses its relationships with those in the Zechstein and Bakevellia Sea basins (Fig. 1).

\section{Regional setting and stratigraphy}

The Upper Permian basin in East Greenland is more than $400 \mathrm{~km}$ long and at least $80 \mathrm{~km}$ wide (Fig. 2). The western limit is a major fault system which separated the depositional basin from the stable Greenland craton during the Carboniferous and subsequent periods (Surlyk et al., 1986).Structural elements which influenced the Late Permian sedimentation are the Liverpool Land and Wegener Halvø highs to the south-east and the Clavering $\varnothing$ high to the north (Figs 1, 2). The Liverpool Land high is inferred to have formed the south-eastern limit of the basin and, as suggested by Maync (1961), the basin was most likely closed towards the south.

The depositional succession starts with fluviatile conglomerates of the Huledal Formation. They are followed by shallow-water, restricted marine limestones and evaporites of the Karstryggen Formation deposited during the initial Late Permian transgression of the basin. The Karstryggen Formation was eroded to produce a palaeokarst terrain. During the succeeding overall rise in sea level the platform carbonates of the Wegener Halvø Formation were deposited along the basin margins and over structural highs while shales of the Ravnefjeld Formation were deposited in the central parts of the basin (Fig. 3). Following another marked fall in relative sea level, sedimentation changed dramatically and the entire basin was filled by shallow-water siliciclastics of the Schuchert Dal Formation (Fig. 3).

The most likely correlation between the East Greenland succession and the Zechstein sediments of NorthWest Europe equates the base of the Zechstein succession 


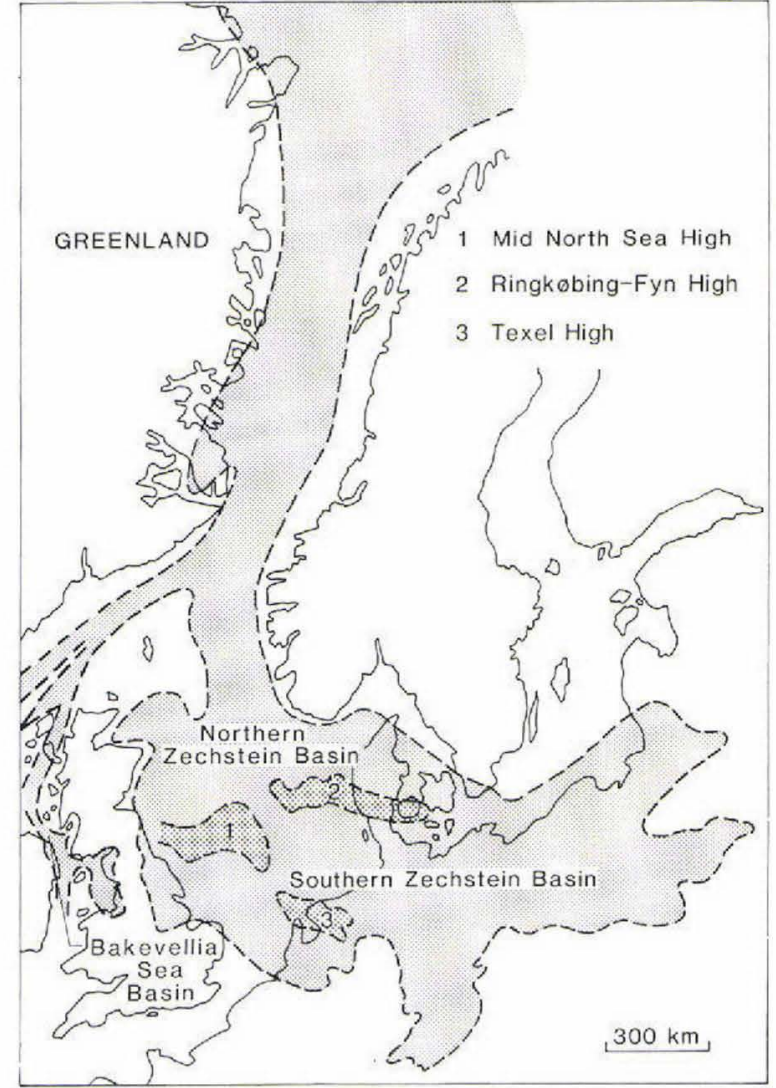

Fig. 1. Late Permian palaeogeography of the North Atlantic rift system.

with the base of the Wegener Halvø and Ravnefjeld formations (Rasmussen et al., 1990; Stemmerik \& Piasecki, 1991). The boundary is regarded as roughly equivalent to the Ufimian-Kazanian boundary in the Russian zonation (Stemmerik, 1995).

\section{General description of the fauna}

The majority of the foraminifera described in this paper were seen in thin-sectioned limestones, largely from the Wegener Halvø Formation (Tables 1-3). Most of these are from the carbonate platform succession on Wegener Halvø along the eastern basin margin, where foraminifera most commonly occur in the more marginal parts of bryozoan build-ups and in biogenic grainstone deposits associated with bryozoans and brachiopods (Stemmerik, 1991). Other foraminifera recorded in Wegener Halvø Formation limestones include a few specimens from deposits of more protected platform environments in the Karstryggen area along the western basin margin and larger assemblages from marginal parts of bryozoan buildups on the Clavering $\emptyset$ high to the north (Figs 1,2).

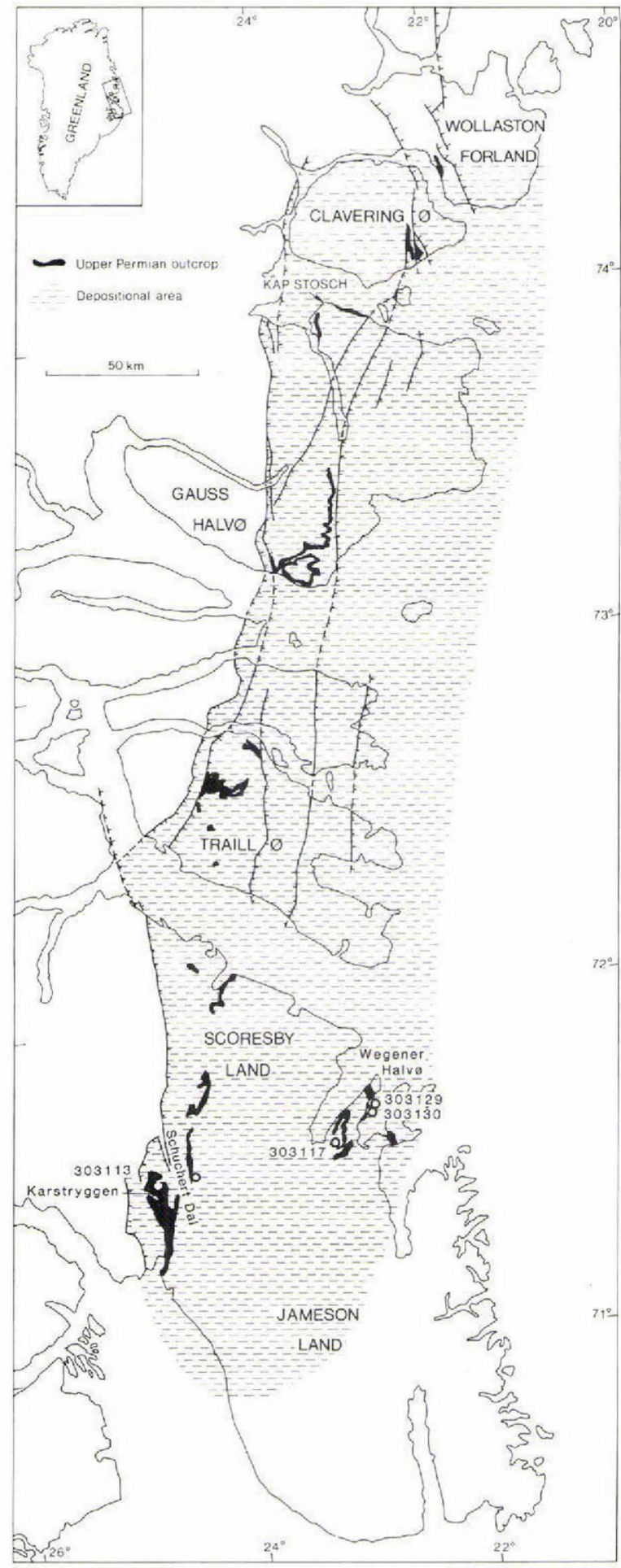

Fig. 2. Outcrops of Upper Permian strata in East Greenland.

Foraminifera have also been noted in two thin sections of limestone from the Karstryggen Formation. In addition, a 


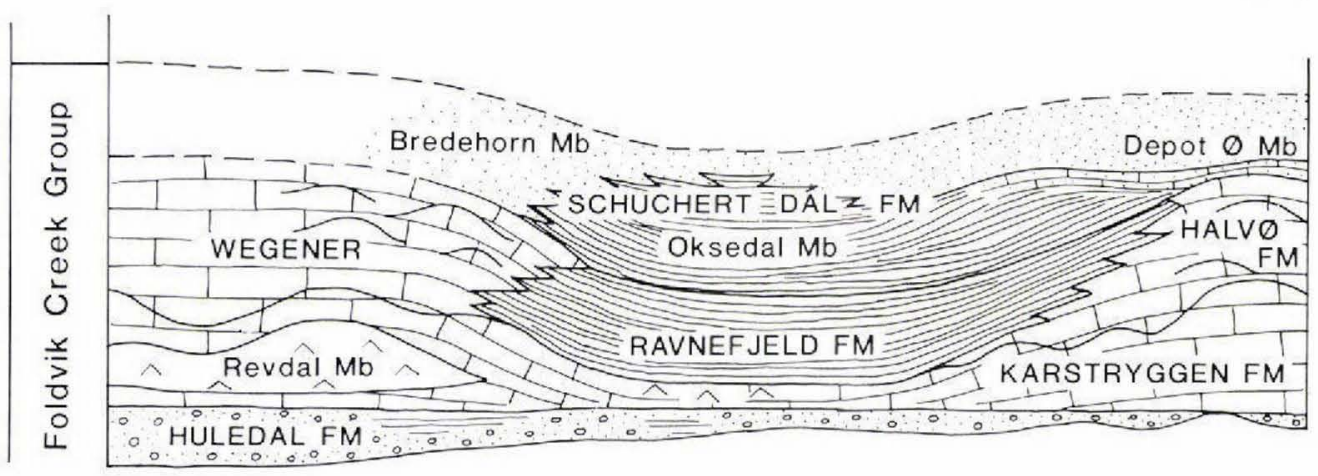

Fig. 3. Permian stratigraphical succession in East Greenland.

number of samples from a section through the top of the Schuchert Dal Formation in a basinal position east of Schuchert Dal have yielded solid specimens of agglutinated foraminifera (Fig. 6).

Table 1. Summary of foraminifera recorded from the East Greenland Permian during this study

\section{Wegener Halv $\phi$ (Wegener Halv $\phi$ Formation)}

Most of the foraminifera recorded from this formation come from three shallow cores drilled through bryozoan build-ups in eastern Wegener Halvø (Figs 2, 4). The largest and most varied fauna is found in core 303129 that was drilled through the marginal parts of a bryozoan
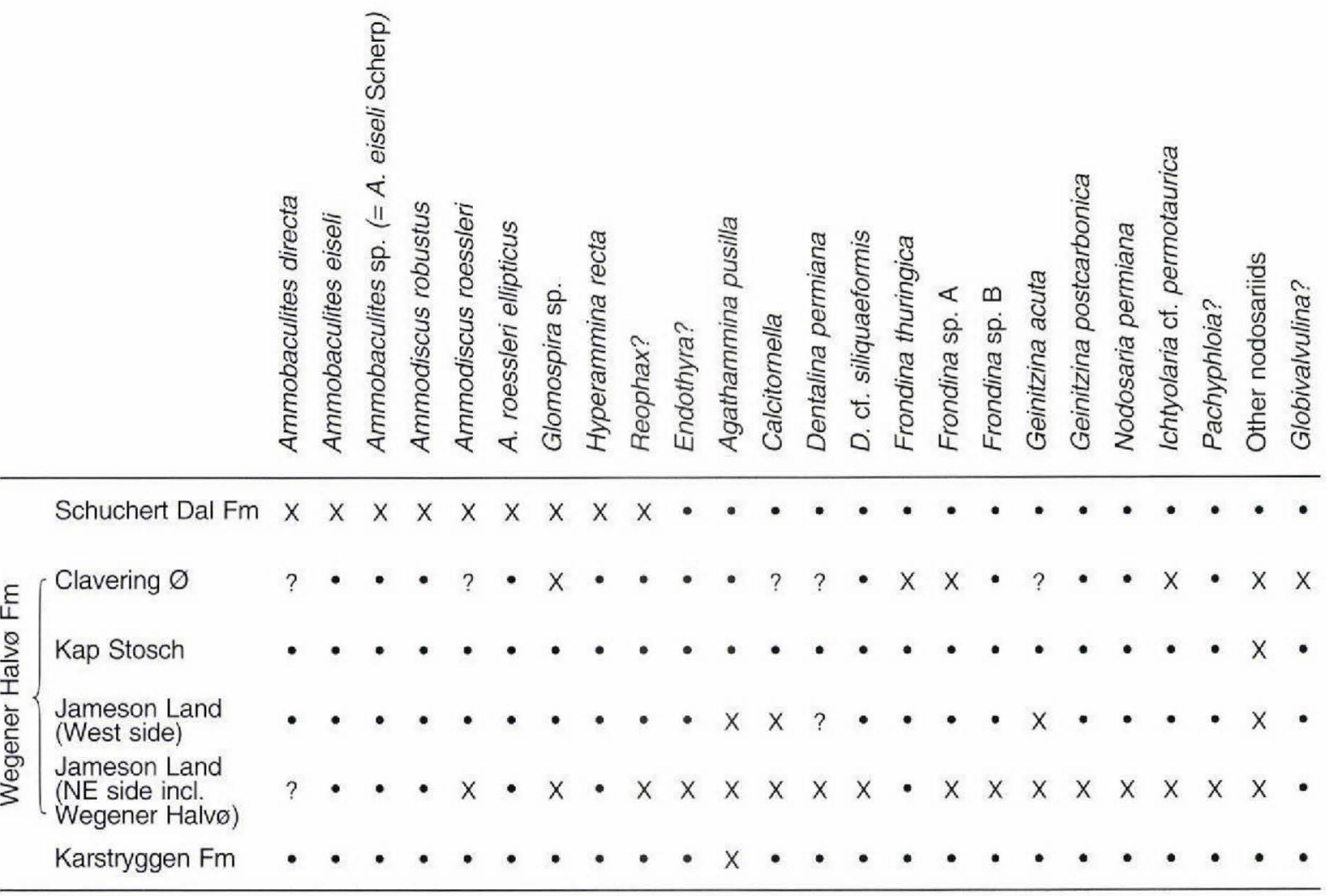
Table 2. Foraminifera recorded from GGU shallow core 303129 on Wegener Halv $\phi$

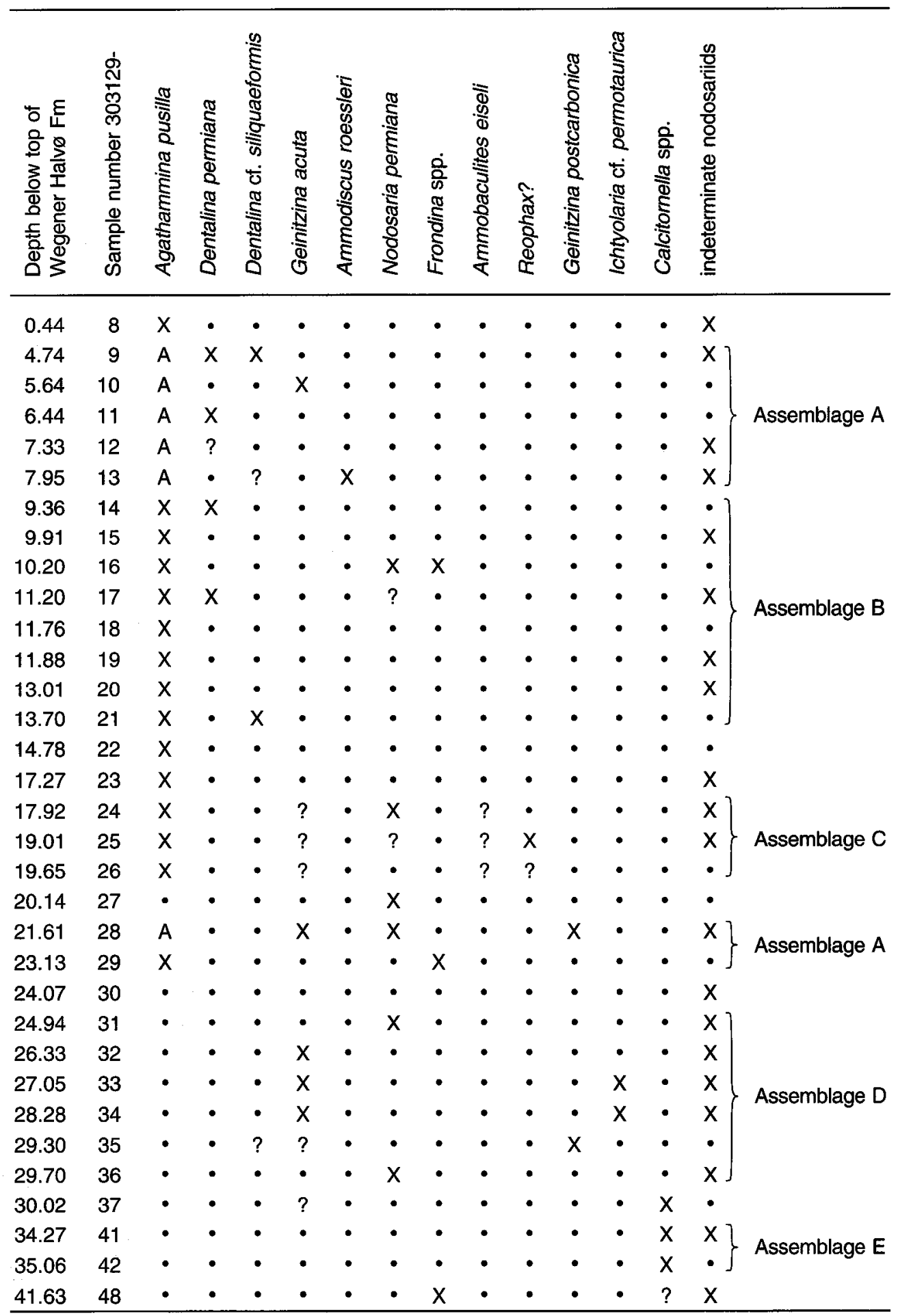

$X=$ recorded,$A=$ abundant 
Table 3. Foraminifera recorded from GGU shallow cores 303113, 303117 and 303130 on Karstryggen and Wegener Halvø

GGU shallow core 303113

Karstryggen

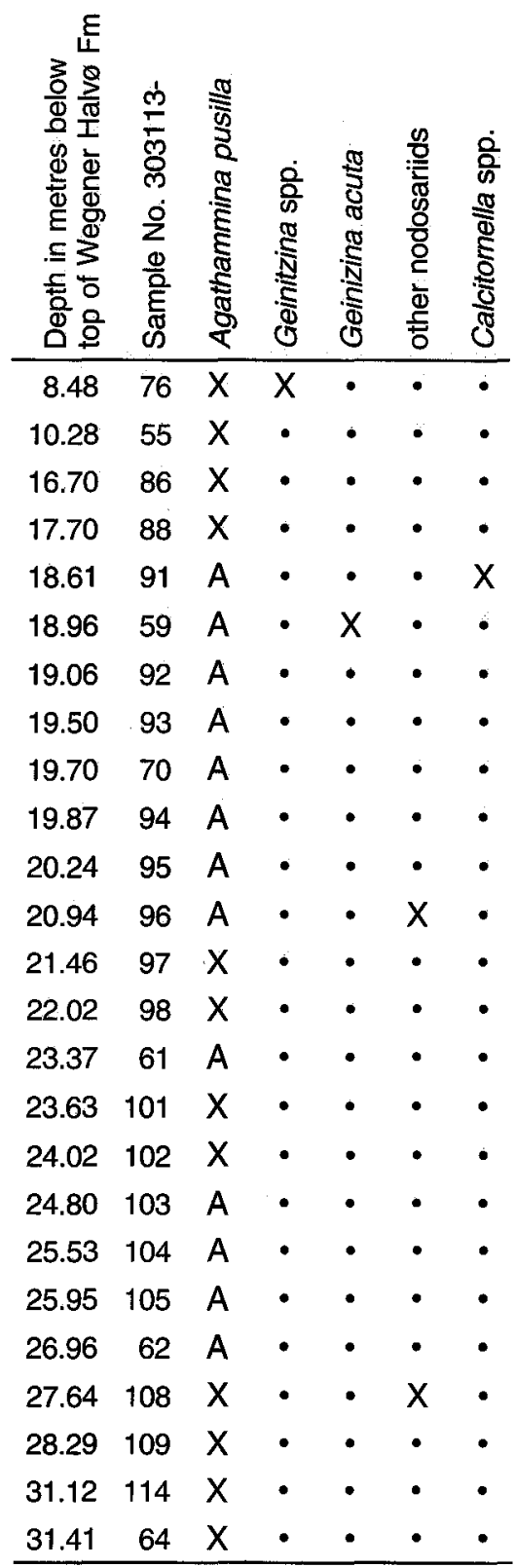

$X=$ recorded $A=$ abundant

\section{GGU shallow core 303117}

Wegener Halvo

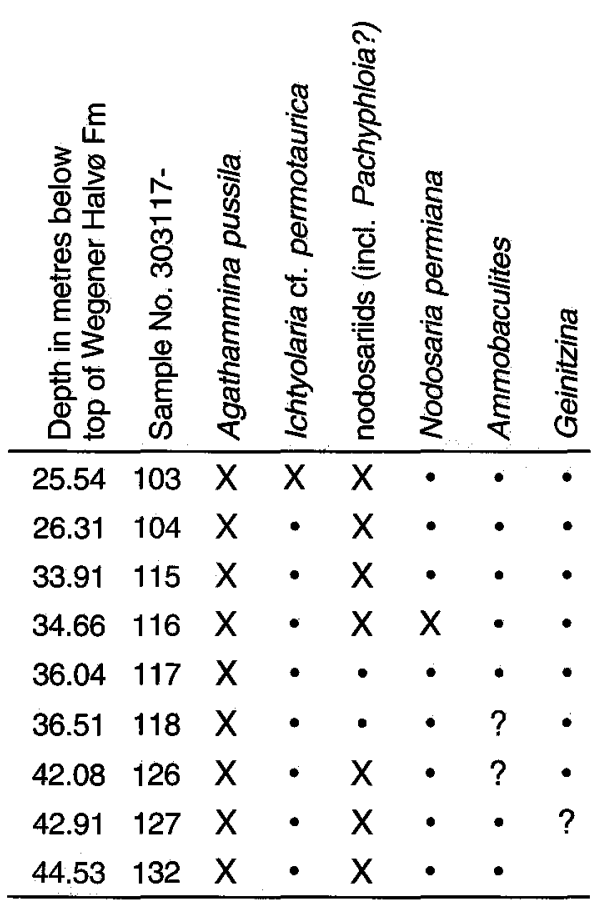

GGU shallow core 303130

Wegener Halvø

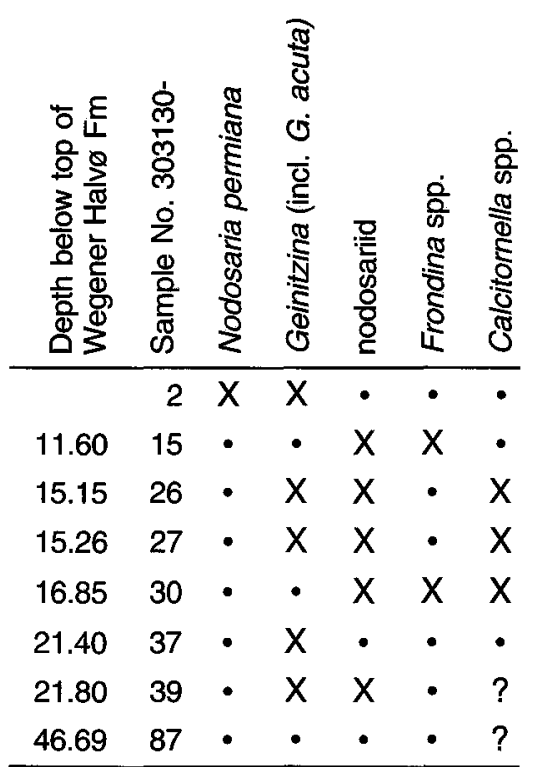




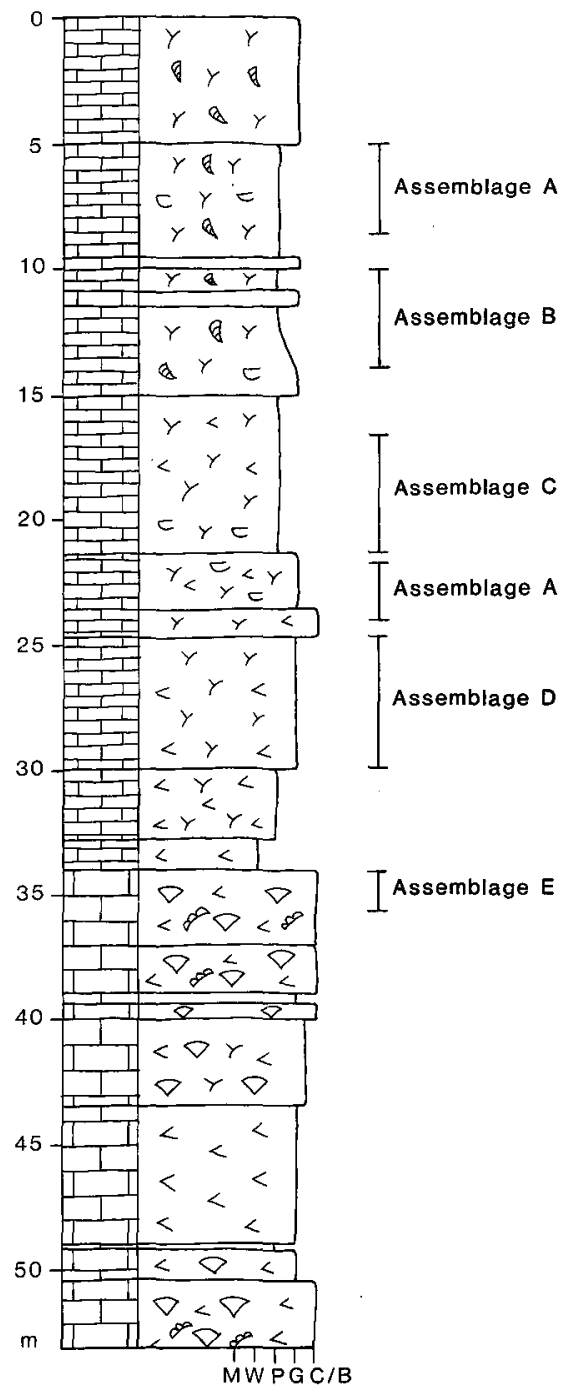

Fig. 4. Sedimentological log of GGU shallow core 303129 on Wegener Halv $\emptyset$ with distribution of foraminifera assemblages.

build-up and reached the build-up core in the basal part (Fig. 4; Stemmerik, 1991). The cored succession contains five distinct assemblages that can be correlated to various carbonate facies (Fig. 4; Table 2).

Assemblage A contains numerous large Agathammina pusilla as well as mostly simple-walled nodosariids, notably Dentalina. It occurs in bryozoan-foraminifer packstones together with abundant cryptostome bryozoans in the interval from $4.75 \mathrm{~m}$ to $8.00 \mathrm{~m}$ and $21.60 \mathrm{~m}$ to $23.15 \mathrm{~m}$ (Fig. 4; Table 2).

Assemblage B contains Agathammina pusilla, although fewer in Assemblage A, and a limited nodosariid fauna. It occurs in bryozoan-foraminifer packstones and grainstones together with cryptostome bryozoans in the interval from $9.40 \mathrm{~m}$ to $13.70 \mathrm{~m}$ (Fig. 4; Table 2).

Assemblage $C$ is comparable to assemblage B but includes some doubtful forms which might be fragmentary Ammobaculites and Reophax. This assemblage occurs in a bryozoan-bivalve packstone with both cryptostome and trepostome bryozoans, and some brachiopods from $17.90 \mathrm{~m}$ to $19.65 \mathrm{~m}$ (Fig. 4; Table 2).

Assemblage $D$ contains a varied nodosariid fauna including Geinitzina and other double-walled forms, such as Ichtyolaria and possibly Pachyphloia. No Agathammina were recorded in this assemblage. Assemblage D occurs in bryozoan-bivalve grainstones from $24.95 \mathrm{~m}$ to $29.70 \mathrm{~m}$ (Fig. 4; Table 2).

Assemblage E contains Calcitornella and nodosariids. It occurs in marine cementstones with comminuted organic debris from $34.25 \mathrm{~m}$ to $35.10 \mathrm{~m}$.

The other two boreholes in the Wegener Halvø area also yielded foraminiferal faunas with a Zechstein aspect (Table 3). The collection from 303130, near 303129, resembles that of Assemblages D and E. It includes Geinitzina, Frondina and abundant Calcitornella, but no Agathammina. This core was drilled through a build-up core, and the fauna occurs in depositional facies similar to those of Assemblage E (cf. Stemmerik, 1991). Borehole 303117, farther south, was drilled through the flanks of a large bryozoan build-up. The fauna yields Agathammina and thick-walled nodosariids and is comparable with Assemblage C of 303129.

Surface samples examined from Wegener Halvø were mostly from the north-eastern end of the peninsula near boreholes 303129 and 303130 . The overall fauna includes the same calcareous porcellanous and nodosariid forms recorded in the boreholes plus the agglutinated Ammodiscus roessleri and Glomospira. One surface sample from the southern part of the area yielded, in addition to the characteristic Zechstein species Geinitzina acuta, an indistinct probable Endothyra, a genus unrecorded in North-West European Zechstein strata.

\section{Karstryggen (Wegener Halv $\emptyset$ and Karstryggen Formations)}

Most of the material examined came from the Wegener Halvø Formation on the western side of the area and included a number of samples from the borehole 303113 . They yielded a monotonous fauna in which Agathammina pusilla was ubiquitous but otherwise only contained 
a few nodosariids, including Dentalina and Geinitzina (Table 3). One other borehole (303101), and surface sampling, from the Wegener Halvø Formation in the western side of the area yielded comparable limited assemblages including Agathammina, Calcitornella and a few nodosariids.

Two samples from the Karstryggen Formation farther east in the area yielded only Agathammina pusilla.

\section{Clavering $\emptyset$ (Wegener Halv $\emptyset$ Formation)}

A total of only six samples from this area yielded a sufficiently large number of species to suggest the presence of a relatively rich foraminiferal fauna with distinct characteristics. No specimens of Agathammina were recorded but the agglutinated genera Ammodiscus, Glomospira and a possible Ammobaculites were seen. The nodosariids, which constitute most of the foraminifera seen, include a greater proportion of broad-tested forms such as Frondina, Geinitzina and Ichtyolaria than in the faunal collections from the Wegener Halvø Formation farther south. In addition, a coiled, chambered foraminifer was seen which might be referred to Globivalvulina, a taxon not recorded elsewhere in East Greenland or in the European Zechstein.

\section{Schuchert Dal (Schuchert Dal Formation and Wordie Creek Group)}

Both palynomorphs and solid foraminifera have been extracted from samples collected from a surface section on the east side of Schuchert Dal. The palynomorphs suggest that the section crosses the Permian-Triassic boundary (S. Piasecki, personal communication), which is taken as the boundary between the Schuchert Dal Formation and the overlying Wordie Creek Group (Fig. 5).

The foraminifera collected from the section are all agglutinated forms which are comparable with European Zechstein material but cannot be regarded as diagnostic of age. The samples from below the postulated boundary are richer than those from above: the latter yielded no Ammobaculites, a genus well-represented in the lower part of the section (Fig. 5). The most prolific sample proved to be that from what is taken to be the top of the Schuchert Dal Formation; specimens from that sample are illustrated in Fig. 6.

\section{Discussion}

These foraminiferal faunas, as might be expected by analogy with the East Greenland Upper Permian brachiopod and bivalve faunas, are comparable with those of the Zechstein and Bakevellia Sea basins. The North-West

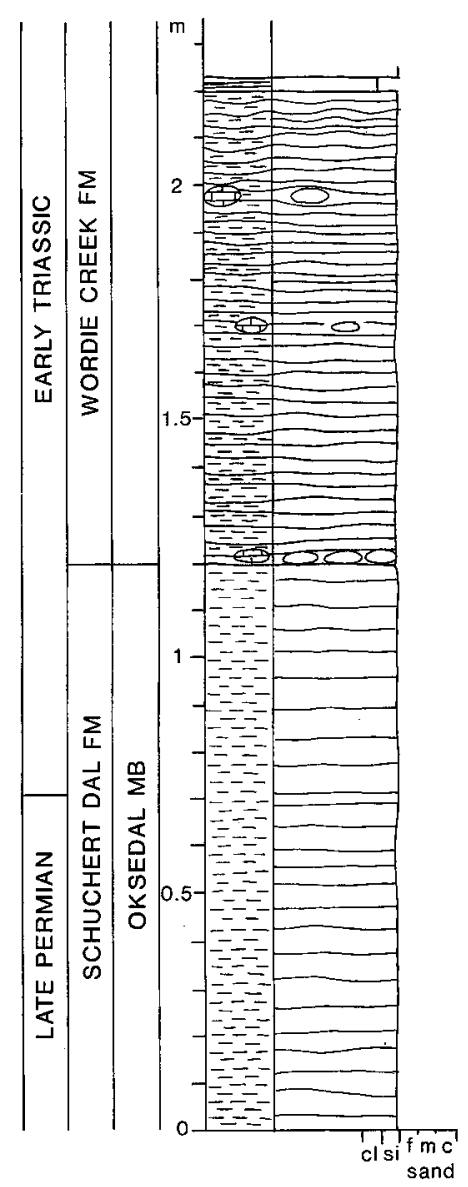

? Ammodiscus robustus Ammodiscus reossleri

Ammodiscus robustus Ammodiscus roessle Hyperammina recta

Ammobaculites directa Ammobacaulites eiseli Ammodiscus robustus Ammodiscus roessler

Glomospira sp. Hyperammina recta Reophax ? poorly preserved ? nodosariids

Fig. 5. Distribution of agglutinated and siliceous foraminifera across the Permian-Triassic boundary in Schuchert Dal.

European Zechstein foraminifera are among the most intensively studied Permian populations of smaller foraminifera (see e.g. Scherp, 1962; Woszczynska, 1968; Pattison, 1989), although much about them remains problematic, especially factors related to test wall structure and composition, and thus to their supra-generic taxonomy. Therefore, inferences about the environmental, stratigraphical and evolutionary significance of the East Greenland foraminifera necessarily draw upon lessons learnt about Zechstein foraminifera but those inferences are limited by similar doubts relating to wall structures and nomenclature.

\section{Palaeoenvironments}

The fauna consist of benthonic, probably epifaunal, relatively shallow-water, assemblages with some indications of varying depths and substrates. The variations of environment inferred from the collections seen, however, 
are limited in range compared with those indicated by known Zechstein foraminiferal faunas.

In Zechstein strata, the foraminiferal assemblage (E) of core 303129, with predominant Calcitornella, would be regarded as indicative of relatively shallow-water facies. The overlying assemblage (D), with Geinitzina but without Agathammina, accompanied by bivalves, is also broadly indicative of shallow water but includes more nodosariid forms than might be expected. Assemblages C, B and A contain Agathammina throughout and declining numbers of Geinitzina, associated with bryozoans (both cryptostome and tepostome) and brachiopods. The interpreted trend towards increased water depth is in line with observations of foraminiferal distribution in Polish Zechstein strata by Peryt \& Peryt (1977). The deepening upward trend inferred from the changes in the foraminifer fauna is supported by microfacies studies of the core (Stemmerik, 1991). Assemblages E and D occur in high energy facies which represent the core of the bryozoan build-ups. Assemblages C, B and A occur in flank deposits surrounding the build-up core, and are accordingly associated with more protected environments. The microfacies indicate a trend towards more protected environments, and abundance of Agathammina seems to be restricted to mud-supported facies.

Analogous inferences can be made from the foraminiferal assemblages yielded by the other two cores of the bryzoan build-ups in the Wegener Halvø area (Table 3). The foraminifera from core 303130 are comparable with assemblages (D) and (E) of 303129 and are similarly associated with abundant marine cement, bivalves and probable algal debris, supportive of a shallow-water, reef core origin (Stemmerik, 1991). The foraminifera, comparable with those of assemblage $C$ of 303129 , yielded by core 303117 occur in build-up flank deposits associated with brachiopods and bryozoans and indicate a deeper water shelf-sea environment. The rest of the material collected from the Wegener Halvø area is broadly indicative of relatively deep, shelf-sea waters.

The limited number of foraminiferal forms yielded by core 303113 (Table 3) in the Karstryggen area together are broadly comparable with the relatively deep-water assemblage (A) of core 303129. They are associated with brachiopods, bryozoans, bivalves and gastropods.

The rich assemblages collected from Clavering $\emptyset$ are less easy to characterise. The species represent considerable variations of water depth, substrate and turbulence and most likely they are reworked from different parts of the bryozoan build-ups.

The presence in North-West European Zechstein strata of agglutinated foraminifera such as those recorded from the section through the top of the Schuchert Dal Formation (Fig. 5), is usually an indication of the availability of suitable adventitious material for incorporation in the test wall. They are most commonly recorded in marginal marine environments where the introduction of terrigenous sediment by rivers can be inferred.

\section{Biostratigraphical correlation}

The established view of what are broadly termed Zechstein rocks in north-west Europe is that they are the products of four or five cycles of mostly evaporitic deposition although this cyclic character is only distinct in the southern part of the main Zechstein basin. There, the first three of those cycles include carbonate units which, together with some associated mudstones, have yielded most of the known marine Zechstein fossils. The first Zechstein cycle carbonate (Z1) contains a fairly rich brachiopod/bryozoan/bivalve/gastropod fauna and varied foraminiferal assemblages. There are considerable lateral variations in the faunal content of the $\mathrm{Z} 1$ carbonate strata due to both palaeoenvironmental and diagenetic factors.

The carbonate units of the next two Zechstein cycles (Z2 and Z3) in the southern part of the Zechstein basin contain faunas which are more limited, both in total numbers and in diversity. The differences between these faunas and those of the first cycle result largely from the elimination of $\mathrm{Z} 1$ species rather than the introduction of new ones and this kind of change is characteristic of the foraminifera as well as the other groups.

In the northern sub-basin of the Zechstein Sea and the contemporaneous Bakevellia Sea to the west the cyclic nature of the deposition is less uniform in character and, in the Bakevellia Sea basin, more difficult to correlate between sub-basins. There is commonly only one marine fossil-bearing carbonate unit in any area and that unit can usually be correlated, in part or in whole, with the first cycle carbonate of the southern part of the main Zechstein basin.

Overall, the North-West European Zechstein faunas lack representatives of several groups of organisms which occur in late Permian marine strata of other parts of the world; notably no ammonoids or fusulinaceans have been recorded. These deficiencies can be largely attributed to postulated land barriers between the Tethyan Ocean, where those groups flourished, and the Zechstein Sea. Consequently, Zechstein faunas, despite their inferred lowlatitude origins, can be regarded as belonging to the Boreal Province, in common with those of the late Permian rocks in East Greenland and other depositional basins associated with the proto-North Atlantic. This distinctive paucity of the Permian Boreal faunas which occur around the present-day North Atlantic and Arctic oceans as well as the Russian Platform was noted by both Gobbett (1973) and Stehli (1973) with reference to the fusulinaceans and brachiopods respectively. 

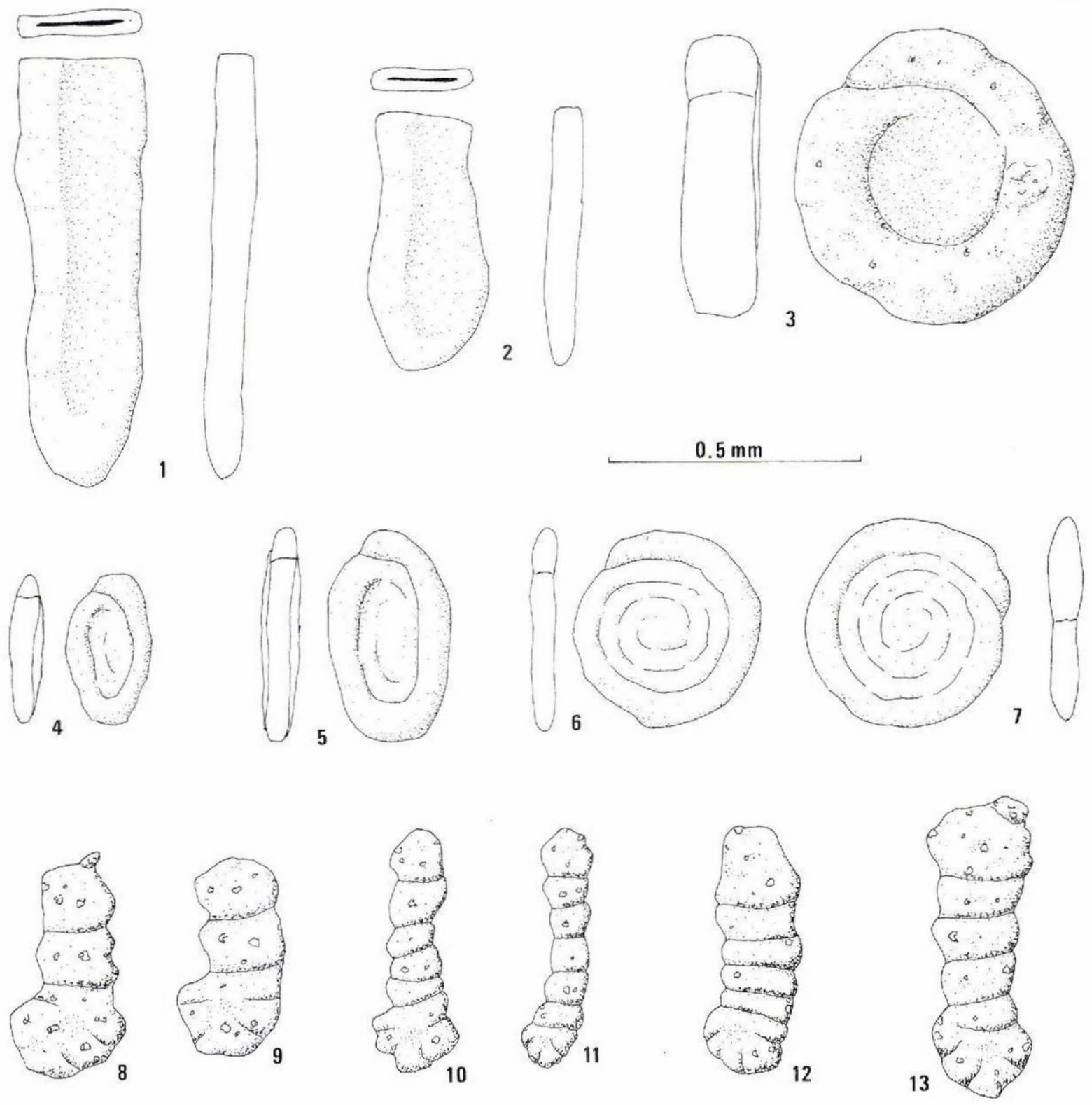

Fig. 6. Agglutinated and siliceous foraminifera, extracted as solid tests, from the top of the Oksedal Member of the Schuchert Dal Formation in Schuchert Dal.

(1) Hyperammina recta Scherp; MGUH 23598. (2) H. recta; MGUH 23599. (3) Ammodiscus robustus Vangerow; MGUH 23600.

(4) Ammodiscus roessleri ellipticus (Spandel); MGUH 23601. (5) A. roessleri ellipticus; MGUH 23602. (6) Ammodiscus roessleri (Schmid); MGUH 23603. (7) A. roessleri; MGUH 23604. (8) Ammobaculites sp. [= A. eiseli Scherp, 1962 ]; MGUH 23605.

(9) Ammobaculites sp. [as previous fig.]; MGUH 23606. (10) Ammobaculites eiseli (Paalzow); MGUH 23607. (11) A. eiseli; MGUH 23608. (12) Ammobaculites directa Scherp; MGUH 23609. (13) A. directa; MGUH 23610.

It must be emphasised that taxonomic uncertainties at both supra-generic and species levels make biostratigraphical correlation between the Zechstein, East Greenland and other late Permian Boreal foraminiferal faunas a somewhat speculative exercise. Broad comparisons between whole assemblages appear to be more useful than correlations based on possibly dubious records of individual species. The numerically best-represented suborders of foraminifera in the East Greenland Upper Permian appear to be the calcareous porcellanous Miliolina and the calcareous, multilocular, uniserial forms here regarded as nodosariids within the Lagenina. Also present are the 
finely siliceous genera Ammodiscus, Glomospira and Hyperammina, and the coarsely agglutinated Ammobaculites. This general composition is entirely comparable with that of the north European Zechstein and other late Permian, non-Tethyan, foraminiferal faunas.

Another similarity with the north European Zechstein fauna is the widespread presence of Agathammina pusilla. The previously noted significance of that species as an indicator of a relatively deep water environment may diminish its biostratigraphical value, but it should be noted that within the Zechstein it is almost diagnostic of a Z1 age. If it does occur in younger Zechstein strata it is extremely rare in them. The species, in its dominance among $\mathrm{Z} 1$ foraminifera, and absence or rarity in $\mathrm{Z} 2$ or $\mathrm{Z} 3$ rocks, is analogous with Bakevellia binneyi among Zechstein bivalves and suggests a correlation of the Wegener Halvø Formation with the first Zechstein cycle. Other miliolids in the Zechstein are more facies-controlled and their absence from the East Greenland samples probably results merely from comparable facies not being represented. They include Cyclogyra and partly planispirallycoiled Agathammina species, characteristic of low-energy, shallow water with mud substrates in the Zechstein; and tightly streptospirally coiled Calcitornella or Orthovertella, common in the core of $\mathrm{Zl}$ barrier reefs.

The nodosariid assemblages are also broadly comparable with those of the first Zechstein cycle including both thin simple-walled Dentalina and Frondina, and more complex, double-layer walled forms referred to Geinitzina, Ichtyolaria and Nodosaria. Woszczynska (1981) reviewed the stratigraphical distribution of nodosariids recorded from Zechstein strata in Europe. All the species she listed from post-Z1 rocks were forms also recorded in first cycle strata. Similar nodosariid assemblages have been described from $\mathrm{Z} 1$ and $\mathrm{Z} 2$ strata in the British Isles, where again, no new forms appeared after the first cycle (Z1). What appear to be comparable nodosariid assemblages were described by Sosipatrova (1972) from Spitsbergen in strata correlated with the Upper Permian Ufimian and Kazanian stages of the Russian Platform.

The nodosariids offer the most promise as biostratigraphical tools among the Boreal late Permian small foraminifera but at present their potential cannot be realised because of the taxonomic confusion surrounding the group. The confusion partly derives from the transitional nature of the group in the late Permian but has been compounded by some inadequate original descriptions of the genera and species to which these foraminifera are usually assigned. Because they include both tests with single-layered and multiple-layered walls they have been variously assigned to two different suborders, the Fusulinina and the Lagenina, but not always with the care that such a major distinction should justify. Mamet \&
Pinard (1990) have described uniserial, rectilinear, calcareous foraminifera from early Permian rocks of the Canadian Arctic Sverdrup Basin which may represent an earlier phase of the transition between these two major groups. In particular, their new genus Nodosinelloides, within the Fusulinina, could include several double-walled species recorded from East Greenland and the European Zechstein, which have been referred to Nodosaria, both here and in previous work. However, the late Permian faunas also include species with thinner, single-layered walls, including some of the Dentalina in this paper, which appear to be more closely related to Mesozoic Lagenina, or may be referable to the genus Protonodosaria, also within the Fusulinina. The authors prefer to retain the mixed generic taxonomy used by most earlier authors for these Permian forms until the wall structures of all the relevant generic type species have been re-examined.

The siliceous or agglutinated forms recorded mostly in the Schuchert Dal section mentioned above, across what is taken to be the Permian-Triassic boundary, are of even less stratigraphical value as they are all long-ranging forms similar to or comparable with foraminifera found in many mudstones of Upper Palaeozoic or later age.

Pending a thorough re-examination of Permian 'nodosariid' taxonomy, the biostratigraphical usefulness of the foraminifera described here must be limited to a general support for the broad correlations already based on the macrofaunas. That is to equate the transgression which initiated the Wegener Halvø and Ravnefjeld formations with that of the first Zechstein cycle (Z1) and to assign a Kazanian age to both. The impact of the transgression was so profound in East Greenland and so sudden and widespread in Europe, where it resulted in the deep-water Kupferschiefer-Marl Slate sea, that a major eustatic sealevel rise seems the probable cause. Given a sea-level rise of such apparent magnitude, it is reasonable to expect that other late Permian marine strata in the Boreal Province were also initiated by it. The faunal evidence suggests that the latter include the earliest marine strata in the various sub-basins of the Bakevellia Sea and contemporaneous marine deposition might be expected to have taken place in half-grabens aligned parallel to the late

Fig. 7.

Magnification $\times 77$

7.1 Agathammina pusilla (Geinitz); [longitudinal section] MGUH 23611 from GGU 303129-8

7.2 Agathammina pusilla; [transverse section]; MGUH 23612 from GGU 303129-9

7.3 Agathammina pusilla; [transverse section]; MGUH 23613 from GGU 303129-10

7.4 Agathammina pusilla; [diagonal section]; MGUH 23614 from GGU 303129-13 

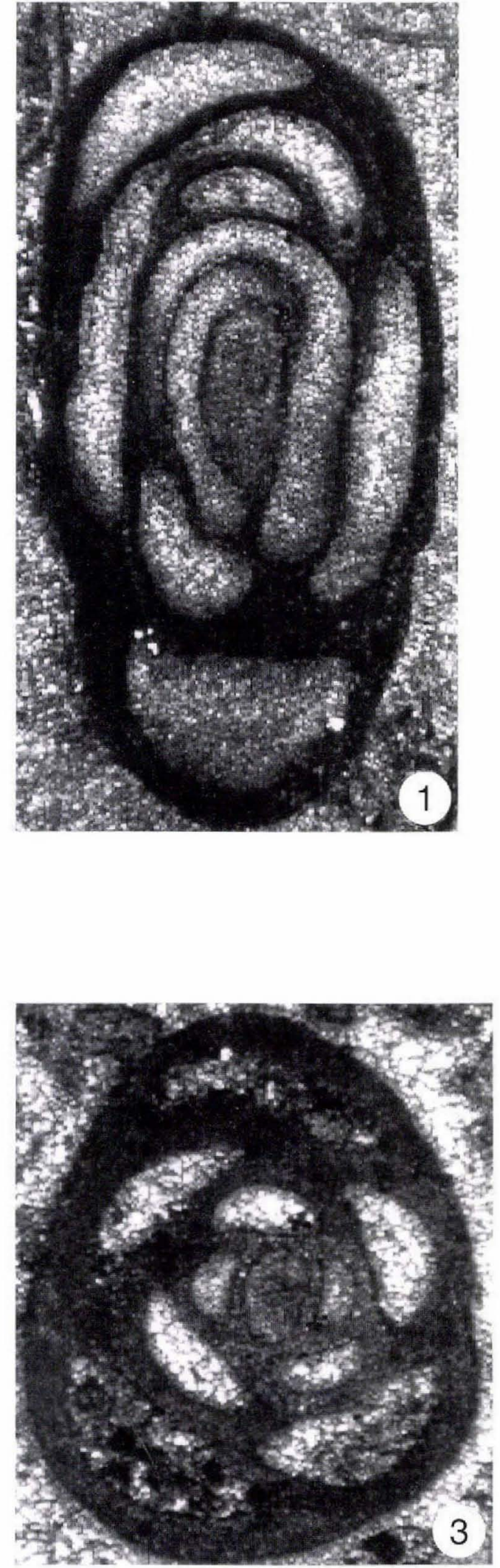
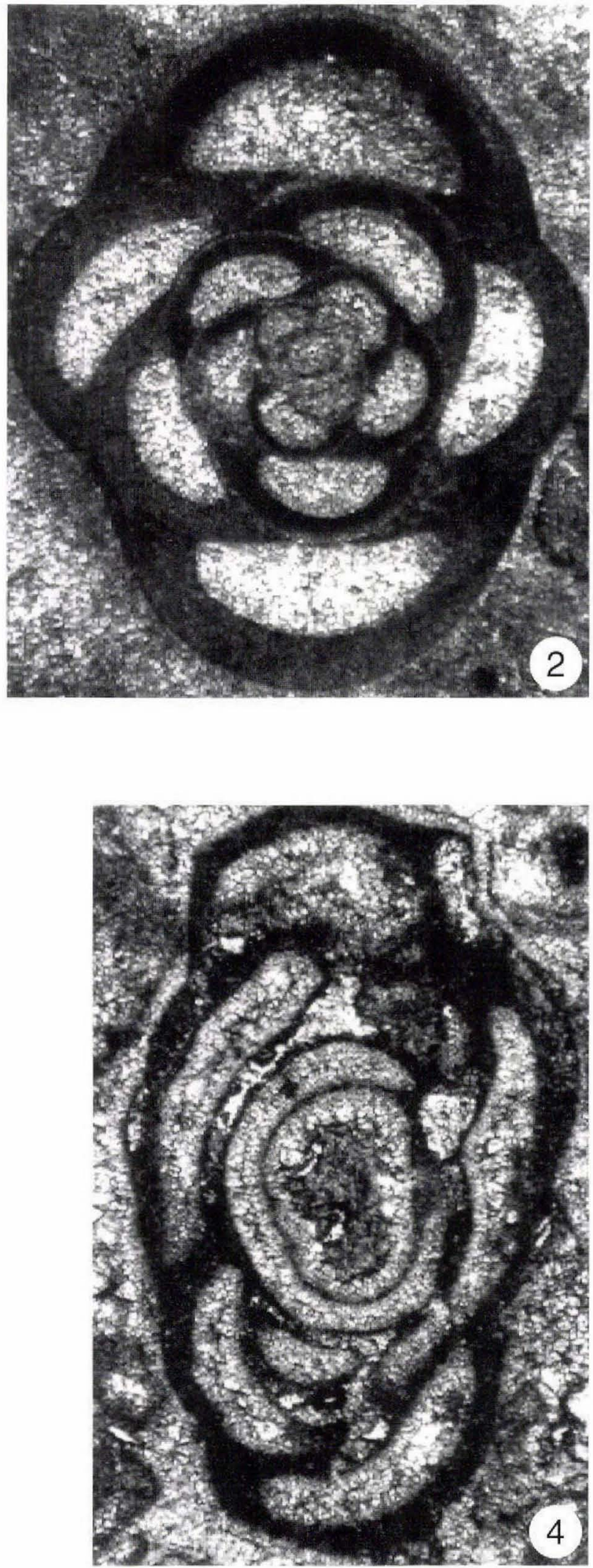
Palaeozoic rift north-west and north of the British Isles and west of Norway.

Outside this simplistic correlation of all the main Permian marine fossil-bearing stratigraphical units in the north Atlantic region the age of several less organicallyrich marine formations is more doubtful. They include older strata such as the Karstryggen Formation in East Greenland and the Banderschiefer, the Mutterfloz and the Zechstein Konglomerat in Germany and Poland. The last three are commonly regarded as local and minor precursors of the Zechstein proper as their faunas have a Zechstein aspect although the brachiopods of the Zechstein Konglomerat form a distinct assemblage. However, a broad correlation between some or all of those three formations and the Karstryggen Formation is possible.

The $\mathrm{Z} 1$ and $\mathrm{Z} 2$ carbonate units, are stratigraphically separate in the southern Zechstein sub-basin, and are usually mutually distinguishable because of the distinctiveness of the $\mathrm{Z} 3$ biota. However, they are not so easily correlated with deposits in the northern sub-basin of the Zechstein or of the Bakevellia Sea. Therefore precise correlation with strata in East Greenland is not feasible and the Wegener Halvø and Ravnefjeld formations must be regarded as broadly equivalent to the unified Halibut carbonate formation of the northern North Sea and all three of the older cycles (Z1-Z3) in the more distal parts of the southern Zechstein sub-basin and the Bakevellia Sea basin.

\section{Brief systematic descriptions}

\section{Suborder Textulariina}

(Mostly seen as solid specimens)

\section{Ammobaculites directa Scherp}

Fig. 6.12, 6.13 = Ammobaculites directa Scherp, 1962.

Remarks. The early coiled part is roughly in line with the rectilinear part and less than 1.5 times its width. The chambers in the coiled part are indistinct. There are 4 to 5 chambers in the rectilinear part; all except the final one are much wider than long. The test wall is coarse-grained with a probable siliceous cement.

\section{Ammobaculites eiseli (Paalzow)}

Fig. 6.10, 6.11 = Ammobaculites eiseli (Spandel) Paalzow, 1936.

Remarks. The early coiled part is slightly offset from the line of the rectilinear part. The chambers in the coiled part are indistinct but less so than in $A$. directa. There are 5 to 6 chambers in the rectilinear part; they are almost as long as wide. Sutures are distinct. The test wall is like that of $A$. directa.

\section{Ammobaculites sp.}

Fig. 6.8, 6.9 = Ammobaculites eiseli (Spandel) Scherp, 1962.

Remarks. The early coiled part is at least $1.5 \times$ the width of the rectilinear part and distinctly offset. The chambers in the coiled part are indistinct. There are 2 to 3 chambers in the rectilinear part; their width and length about equal. The test wall is like those of $A$. directa and A. eiseli.

\section{Ammodiscus robustus Vangerow}

Fig. 6.3 = Ammodiscus robustus Vangerow, 1962.

Remarks. The test consists of a planispirally coiled tube. Coiling is involute; the inner whorls and aperture are indistinct. The final whorl is thick. The test wall is fairly coarse-grained; the cement probably siliceous.

\section{Ammodiscus roessleri (Schmid)}

Fig. 6.6, 6.7, 8.2 = Serpula roessleri Schmid, 1867.

Remarks. The test is discoid and consists of a proloculus followed by a planispirally coiled, tubular second chamber. The tubular chamber increases slowly in width. The aperture is indistinct. The test wall is fine-grained and probably siliceous. The species has been seen both as solid specimens and in thin section.

\section{Ammodiscus roessleri ellipticus (Spandel)}

Fig. 6.4, 6.5 = Trochammina bradyna elliptica Spandel, 1898

Remarks. The test consists of a planispirally coiled tube but has an overall ovoid shape. This form is possibly a

Fig. 8

Magnification $\times 77$

8.1 Calcitomella sp.; MGUH 23615 from GGU 292697

8.2 Ammodiscus roessleri (Schmid); [approximate axial section]; MGUH 23616 from GGU 357316-1

8.3 Glomospira sp.; [approximate axial section]; MGUH 23617 from GGU 357316-2

8.4 Endothyra?; MGUH 23618 from GGU 298134

8.5 Calcitornella sp.; MGUH 23619 from GGU 303113-91

8.6 Dentalina permiana Jones; MGUH 23620 from GGU 303129-14

8.7 Dentalina cf. siliquaeformis Sossipatrova; MGUH 23621 from GGU 393129-21

8.8 D. cf. siliquaeformis; MGUH 23622 from GGU 303129-9 

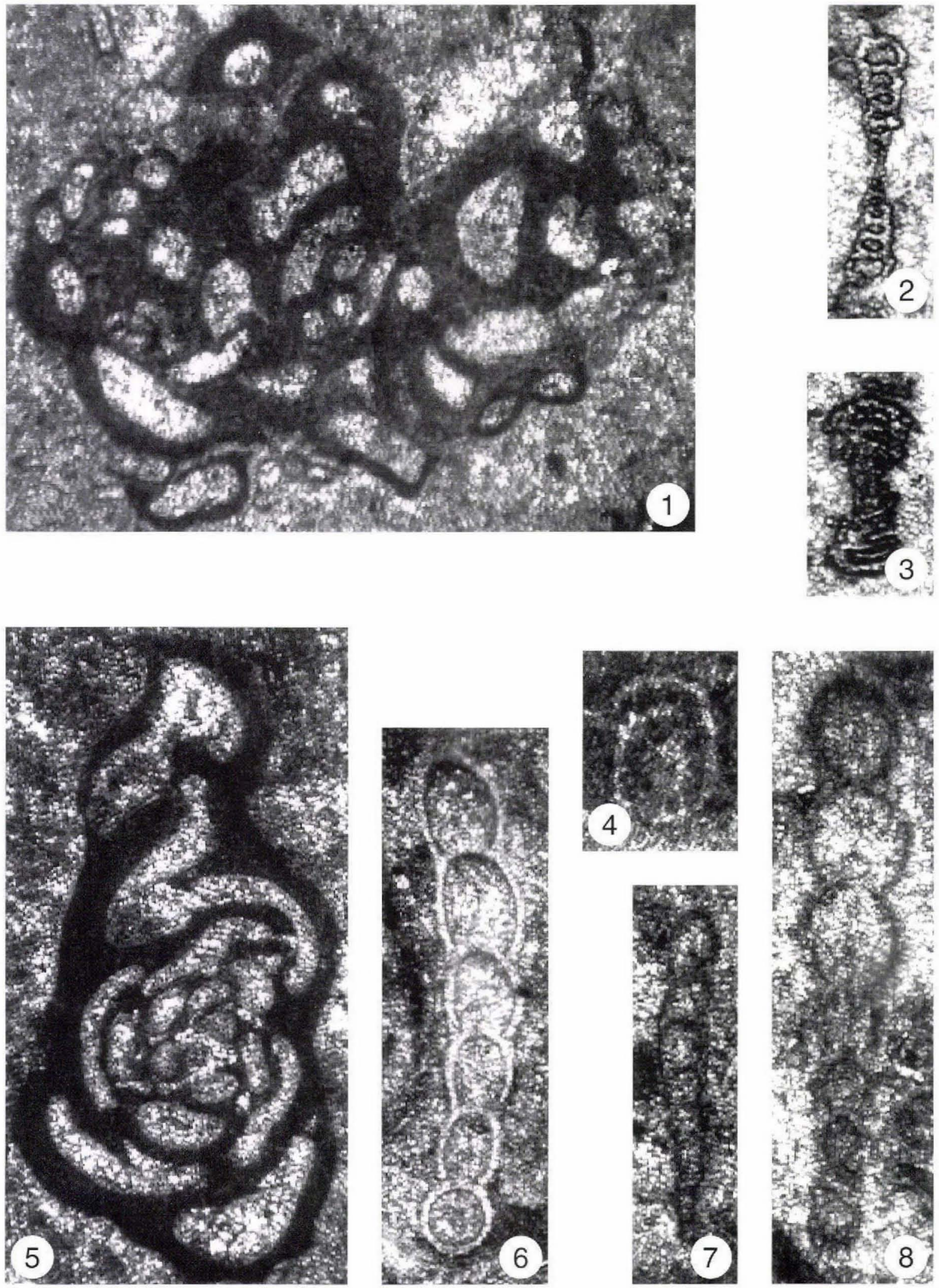
distorted, originally discoid, $A$. roessleri sensu stricto, but was recognised as a distinct subspecies by Spandel.

\section{Glomospira sp.}

Fig. 8.3

Remarks. The test (seen only in thin-section) consists of a proloculus and a tubular second chamber. The latter is streptospirally coiled initially but possibly becomes more evolute. The transverse section of the tube is a compressed semi-circle. The tube increases slowly in width.

\section{Hyperammina recta Scherp}

Fig. 5.1, 5.2 = Hyperammina clavacoidea recta Scherp, 1962.

Remarks. The test is an elongate, compressed, simple tube with a bulbous early part which could be regarded as a proloculus. The aperture is slit-like. The test wall is fine-grained and probably siliceous.

\section{Rephax?}

Remarks. The test is multilocular, uniserial and rectilinear with a coarse-grained agglutinated wall comparable with that of Ammobaculites. Only doubtful, possibly fragmentary, specimens have been seen, both as solid tests and in thin-section.

\section{Suborder Fusulinina}

\section{Endothyra?}

Fig. 8.4

Remarks. Seen in thin-section as a planispirally coiled test with short intercameral septa. The test wall is indistinct, but appears to be transparent and singlelayered. Reference to the genus Endothyra is dubious, merely serving to indicate a possible familial assignment.

\section{Suborder Miliolina}

(Seen only in thin-section)

\section{Agathammina pusilla (Geinitz)}

Fig. 7.1-7.4 = Serpula pusilla Geinitz, 1848 [part]

Remarks. The test is elongate and fusiform, consisting of a globular proloculus followed by a tubular second chamber coiled in a quinqueloculine manner. The transverse section of the second chamber is hemispherical. The test wall is calcareous and mostly appears homogeneous and grey, but is commonly recrystallised to clear calcite.

\section{Calcitornella spp.}

Fig. 8.2, 8.5

Remarks. The test consists of a proloculus followed by a tubular second chamber. The latter increases slowly in diameter; it is irregularly coiled, sometimes in an involute streptospiral, sometimes in an evolute body of variable shape. The transverse section of the tube in the involute tests is hemispherical; in the evolute forms, it can be circular. The test wall is like that of Agathammina pusilla. Most of these foraminifera in the East Greenland material appear to be attached to other organic debris: bryozoa etc. However, it is possible that they include free forms which, although similar in every other respect, should properly be assigned to Orthovertella.

\section{Suborder Lagenina}

The uniserial, rectilinear, calcareous, multilocular foraminifera comprising a large part of these faunas are all described here under the heading of the Lagenina. They were all seen only in thin-sections.

Fig. 9

Magnification $\times 77$

9.1 Frondina sp. A; MGUH 23623 from GGU 346190

9.2 Frondina sp. A; MGUH 23624 from GGU 303130-30

9.3 Frondina sp. B; MGUH 23625 from GGU 303129-48

9.4 Frondina thuringica (Paalzow); MGUH 23626 from GGU 360652

9.5 Geinitzina postcarbonica Spandel; MGUH 23627 from GGU 303129-35

9.6 Nodosaria permiana (Spandel); MGUH 23628 from GGU 303117-116

9.7 Pachyphloia?; MGUH 23629 from GGU 303117-132

9.8 Geinitzina acuta (Spandel); MGUH 23630 from GGU 303113-59

9.9 G. acuta; MGUH 23631 from GGU 303130-37

9.10 G. acuta; MGUH 23632 from GGU 298134

9.11 Nodosaria permiana; MGUH 23633 from GGU 357539

9.12 Pachyphloia?; MGUH 23634 from GGU 303129-28

9.13 chtyolaria cf. permotaurica Civrieux \& Dessauvagie; MGUH 23635 from GGU 303117-103

9.14 Globivalvulina?; MGUH 23636 from GGU 360653 

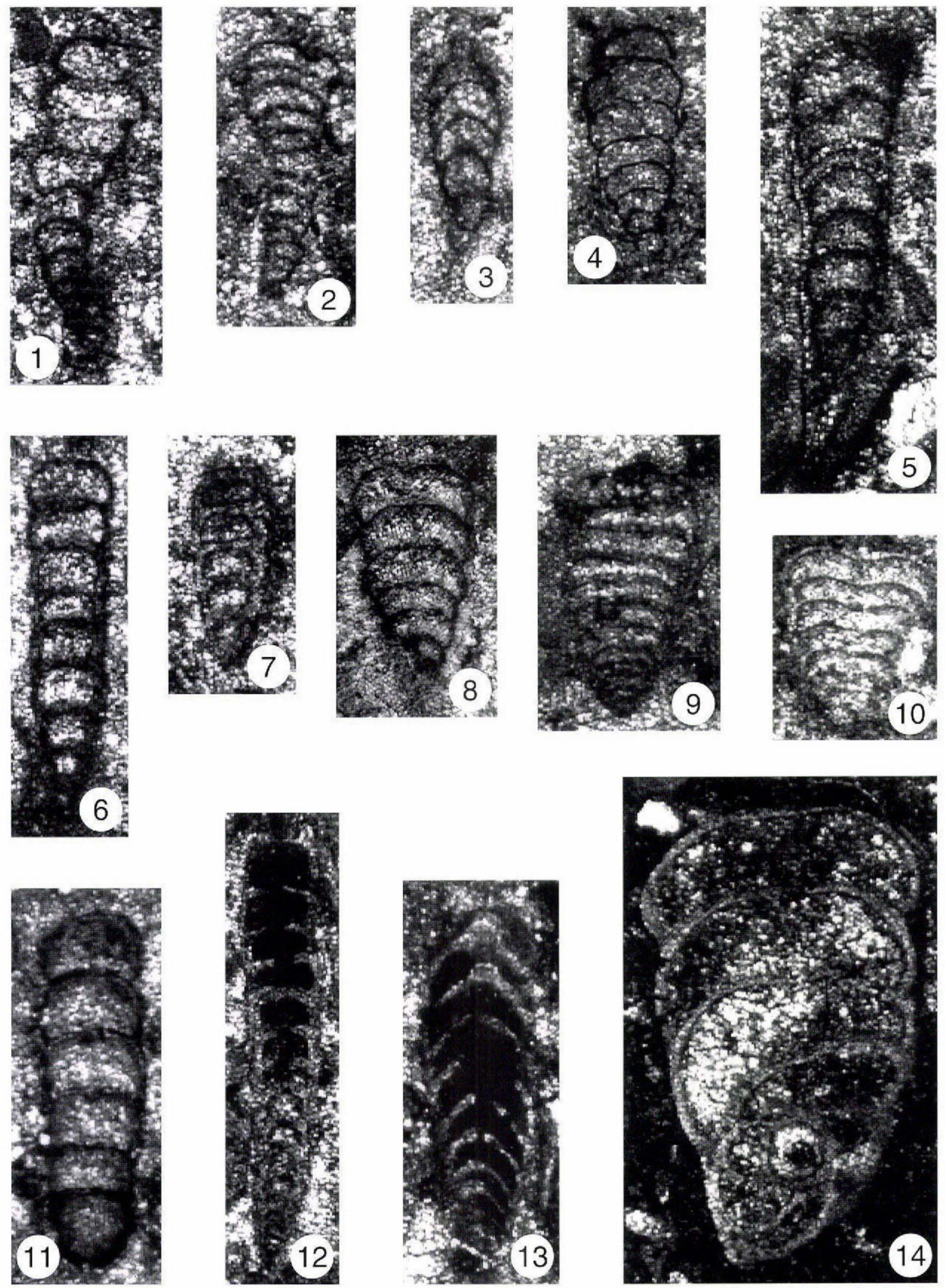


\section{Dentalina permiana Jones}

Fig. 8.6 = Dentalina permiana Jones, 1850 .

Remarks. The test is multilocular and uniserial. It typically has 6 to 9 chambers, each a slender barrel shape, mostly longer than wide, increasing in size although the proloculus may be about the same size as the second chamber. The chambers are arranged in a gentle arc. The test wall is commonly thin and clear, rarely with a very thin, dark, inner layer.

\section{Dentalina cf. $D$. siligaeformis Sosipatrova}

Fig. 8.7, 8.8

Remarks. As D. permiana but with narrower chambers. The curvature of the test is less regular, and may comprise two arcs facing in opposite directions. Comparable forms, from the Polish Zechstein, were assigned to D. siliqueformis Sosipatrova, 1969, by Peryt \& Peryt (1977).

\section{Frondina thuringica (Paalzow)}

Fig. 9.4 = Spandelina thuringica Paalzow, 1936.

Remarks. The test is multilocular and uniserial with a slightly arcuate line of up to 10 chambers. The latter are irregularly shaped but are all wider than long, and mostly slightly arched over the previous chamber. The test wall is very thin, simple and appears dark in thin-section under ordinary light.

\section{Frondina sp. A}

Fig. 9.1, 9.2

Remarks. As $F$. thuringica but the chambers are wider and more irregularly shaped.

\section{Frondina sp. B}

Fig. 9.3

Remarks. As previous two species but the test is less arcuate and has distinctly arched chambers.

\section{Geinitzina acuta (Spandel)}

Fig. 9.8-9.10 = Geinitzella acuta Spandel, 1898.

Remarks. The test is multilocular, rectilinear and uniserial but simulating biserial by having a longitudinal central compression. A spherical proloculus is followed by compressed chambers which initially increase quickly in width. The last part of the test may be parallel-sided. The test wall is double, with a dark inner layer and a generally thicker, paler outer layer.

\section{Geinitzina postcarbonica Spandel}

Fig. 9.5 = Geinitzina postcarbonica Spandel, 1901.

Remarks. As G, acuta but longer and narrower, with a greater proportion of the test parallel-sided.

\section{Nodosaria permiana (Spandel)}

Fig. 9.6, 9.11 = Orthocerina permiana Spandel, 1898 .

Remarks. The test is multilocular, rectilinear and uniserial. A spherical proloculus is followed by generally barrelshaped chambers which are mostly longer than wide. The test wall commonly appears double, with a thin dark inner layer and a thicker, pale outer layer. This species, both here and in the European Zechstein, might be referable to the genus Nodosinelloides Mamet \& Pinard but see discussion earlier on nodosariids.

\section{Ichtyolaria cf. I. permotaurica Civrieux \& Dessauvagie}

Fig. 9.13

Remarks. The test is multilocular, rectilinear and uniserial. A spherical proloculus is followed by chambers which increase rapidly in width. They are much wider than long and have a chevron shape in thin-section, each embracing the previous chamber. The test wall is thin, simple and clear. The species 1 . permotaurica was erected for externally striate forms from Upper Permian strata in Anatolia, Turkey by Civrieux \& Dessauvagie (1965).

\section{Pachyphloia ?}

Fig. 9.7, 9.12

Remarks. Several specimens with thick, clear, but possibly lamellar test walls have been tentatively assigned to this genus although none of them show the pronounced median wall thickening visible in longitudinal axial sections of typical forms of the genus. They are comparable with the specimens from the Polish Zechstein assigned to Pachyphloia exilis Luperto by Peryt \& Peryt (1977). 
Other form, of doubtful taxonomic assignment

Fig. 9.14

One thin-section of material (sample GGU 360653) from the Wegener Halvø Formation of Clavering $\emptyset$ shows a coiled, multilocular foraminifer with a clear calcareous test wall. It may be referable to Globivalvulina although one non-axial section constitutes insufficient evidence for anything other than a tentative suggestion.

Acknowledgements. The authors wish to thank Dr. S. Piasecki for invaluable help with the photography and Dr. I. P. Wilkinson for his constructive comments on the text.

\section{References}

Christiansen, F. G., Piasecki, S., Stemmerik, L. \& Telnæs, N. 1993: Depositional environment and organic geochemistry of the Upper Permian Ravnefjeld Formation source rock in East Greenland. Amer. Assoc. Petrol. Geol. Bull. 77, 1519-1537.

Civrieux, J. M. S. \& Dessauvagie, T. F. J. 1965: Reclassification de quelques Nodosariidae, particulièrement du Permien au Lias. Maden Tetkik Arama Enstit. Yayinl. 124, 178 pp.

Dunbar, C. O. 1955: Permian brachiopod faunas of central East Greenland. Meddr Grønland 110(3), 172 pp.

Geinitz, H. B. 1848: Die Versteinerungen des deutschen Zechsteingebirges, $26 \mathrm{pp}$. Dresden \& Leipzig.

Gobbett, D. J. 1973: Permian Fusulinacea. In Hallam, A. (ed.) Atlas of palaeobiogeography. Amsterdam: Elsevier.

Jones, T. R. 1850: In King, W. (ed.) A monograph of the Permian fossils of England. Palaeontogr. Soc. [Monogr.], $258 \mathrm{pp}$.

Mamet, B. \& Pinard, S. 1990: Notes sur la taxonomie des petites foraminifères des Palaeozoic Superière. Bull. Soc. Belg. Geologie, 99 (3/4), 373-398.

Maync, W. 1961: The Permian of Greenland. In Raasch, G. O. (ed.) Geology of the Arctic 1, 214-223. Univ. Toronto Press.

Newell, N. D. 1955: Permian pelecypods of East Greenland. Meddr Grønland 110 (4), 36 pp.

Paalzow, R. 1936: Die Foraminiferen im Zechstein des östlichen Thüringen. Jb. preuss. geol. Landesanst. 56, 26-45.

Pattison, J. 1989: Permian. In Jenkins, D. G. \& Murray, J. W. (ed.) Stratigraphical atlas of fossil foraminifera, 87-96. Chichester: Ellis Horwood.

Peryt, T. M. \& Peryt, D. 1977: Otwornice cechszty skie monokliny Przedsudeckiej i ich paleoekologia. Rocznik. Pol. Towarzystwa geol. 47, 301-326.

Piasecki, S. 1984: Preliminary palynostratigraphy of the Permian - Lower Triassic sediments in Jameson Land and Scoresby Land, East Greenland. Bull. Geol. Soc. Denmark 32, 139-144.

Rasmussen, J. A., Piasecki, S., Stemmerik, L. \& Stouge, S. 1990: Late Permian conodonts from central East Greenland. Neues Jb. Geol. Palaont. Abh. 178 (3), 309-324.

Scherp, H. 1962: Foraminiferen aus dem Unteren und Mittleren Zechstein Nordwestdeutschlands. Fortschr. Geol. Rheinld West. 6, 265-330.
Schmid, E. E. 1867: Über die kleineren organischen Formen des Zechsteinkalks von Selters in der Wetterau. Neues $\mathrm{Jb}$. Geol. Petrefacten-Kunde 1867, 576-588.

Scholle, P. A., Stemmerik, L. \& Ulmer, D. S. 1991: Diagenetic history and hydrocarbon potential of Upper Permian carbonate buildups, Wegener Halvø area, Jameson Land Basin, East Greenland. Amer. Assoc. Petrol. Geol. Bull. 75 (4), 701-725.

Scholle, P. A., Stemmerik, L., Ulmer-Scholle, D., di Liegro, G. \& Henk, F. H. 1993: Palaeokarst-influenced depositional and diagenetic patterns in Upper Permian carbonates and evaporites, Karstryggen area, central East Greenland. Sedimentology 40, 895-918.

Sosipatrova, G. P. 1972: [Upper Palaeozoic foraminifera of Spitzbergen]. In Sokalov, V. N. \& Vasilevskaja, N. D. (ed.) [Stratigraphy of Spitzbergen ], 126-163. Leningrad: NIIGA. (in Russian).

Spandel, E. 1898: Die Foraminiferen des deutschen Zechsteines. Nürnberg, $15 \mathrm{pp}$.

Spandel, E. 1901: Die Foraminiferen des Permo-Carbon von Hooser, Kansas, Nord Amerika. Festschrift Nat. Ges. Nïrnberg 1901, 175-194.

Stehli, F. G. 1973: Permian brachiopods. In Hallam, A. (ed.) Atlas of palaeobiogeography, 143-149. Amsterdam: Elsevier.

Stemmerik, L. 1987: Cyclic carbonate and sulphate from the Upper Permian Karstryggen Formation, East Greenland. In Peryt, T. M. (ed.) The Zechstein Facies in Europe, 5-22, Lecture notes in Earth Sciences, 10. Berlin, Heidelberg: Springer-Verlag.

Stemmerik, L. 1991: Reservoir evaluation of Upper Permian buildups in the Jameson Land basin, East Greenland. Rapp. Grønlands geol. Unders. 149, 23 pp.

Stemmerik, L. 1995: Permian history of the Norwegian-Greenland Sea area. In Scholle, P. A., Peryt, T. M. \& Ulmer-Scholle, D. S. (ed.) The Permian of northern Pangea, 2: Sedimentary basins and economic resources, 98-118. Berlin: Springer Verlag.

Stemmerik, L. \& Piasecki, S. 1991: The Upper Permian of East Greenland - a review. Zbl. Geol. Palaont. 1991, 1(4), 825-837.

Stemmerik, L., Rouse, J. E. \& Spiro, B. 1988: S-isotope studies of shallow water, laminated gypsum and associated evaporites, Upper Permian, East Greenland. Sedimentary Geology 58, $37-46$.

Stemmerik, L., Christiansen, F. G., Piasecki, S., Jordt, B., Marcussen, C. \& Nøhr-Hansen, H. 1993: Depositional history and petroleum geology of the Carboniferous to Cretaceous sediments in the northern part of East Greenland. In Vorren, T.O. et al. (ed.) Arctic Geology and Petroleum Potential. Norwegian Petroleum Society Special Publ. 2, 67-87.

Surlyk, F., Hurst, J. M., Piasecki, S., Rolle, F., Scholle, P. A., Stemmerik, L. \& Thomsen, E. 1986: In Halbouty, M. T. (ed.) Future petroleum provinces of the world. Mem. Amer. Assoc. Petrol. Geol. 40, 629-659.

Utting, J. \& Piasecki, S. 1995: The palynology of the Permian of the northern continents: a review. In Scholle, P. A., Peryt, T. M. \& Ulmer-Scholle, D. S. (eds) The Permian of northern Pangea, 1, 236-261. Berlin: Springer Verlag.

Vangerow, E. F. 1962: Über Ammodiscus aus dem Zechstein. Paläont. Z. 36 (1/2), 125-133.

Woszczynska, S. 1968: Wstepne wyniki badan mikrofauny osadow cechsztynu. Kwart. Geol. 12(1), 92-104. 
Woszczynska, S. 1981: Foraminifera and Ostracoda of the Zechstein carbonate rocks in the Polish lowlands. In Depowski, S., Peryt, T. M. \& Piatkowski, T. S. (ed.) Proceedings of International Symposium on Central European Permian, 502-515. Warszawa: Wydawnicta Geologiczne. 